\title{
Regional identity in a geopolitically contested area: Preševo Valley (South Serbia) scientific argumentation and political use
}

\author{
Identidad regional en un área de disputa geopolítica: \\ el Valle de Preševo entre la argumentación científica y el uso político
}

\author{
Arsim Ejupi ${ }^{1}$ (D) \\ Miguel Borja Bernabé-Crespo ${ }^{2 *}$ (I)
}

\begin{abstract}
This paper discusses the theoretical and methodological principles in the process of regionalization and analyzes the criteria used during the designation of the region as a category of special importance in geographical research. Methodological principles of regionalization were applied during the differentiation of the Preševo Valley as an individualized region. The Preševo Valley is a small region in South Serbia with a very favorable geographical position because it is located in the central part of the Balkan Peninsula between the Morava and Vardar valleys. Theoretical and methodological discussion highlights elements of a geographical and socio-economic basis that contribute to a regional-geographical differentiation of the area, as well as those elements that appear as an obstacle in attempts to differentiate this area in regional terms. A critical overview of the use of the name 'Preševo Valley' between scientific argumentation and political usage is also given. A survey was carried out to identify the main elements that constitute Preševo Valley's regional identity. The main results show that this region is characterized by a mostly Albanian population, poor economic development, high migration rates, strategic position, and a strong national consciousness.
\end{abstract}

Keywords: region; identity; regionalization; Preševo Valley; Serbia.

\section{Resumen}

Este artículo discute los principios teóricos y metodológicos en el proceso de regionalización, y analiza los criterios utilizados durante la designación de la región como categoría de especial importancia en la investigación geográfica. Se han aplicado los principios metodológicos de regionalización en la diferenciación del Valle de Preševo como región individualizada. El Valle de Preševo es una pequeña región del sur de Serbia con una posición geográfica muy favorable ya que se encuentra en la parte central de la península balcánica, entre los valles del Morava y Vardar. Se ha procedido a la discusión teórica y metodológica para resaltar aquellos elementos de base natural-geográfica y socioeconómica que contribuyen a la diferenciación regional-geográfica, así como aquellos que representan un obstáculo en los intentos de diferenciar esta área en términos regionales. Igualmente, se ofrece una descripción crítica del uso del nombre "Valle de Preševo" entre la argumentación científica y el uso político. Se ha llevado una encuesta para identificar los principales elementos que constituyen la identidad regional del Valle de Preševo. Los principales resultados muestran que esta región está caracterizada por una mayoría de población étnica albanesa, con escaso desarrollo económico, altas tasas de emigración, posición estratégica y fuerte conciencia nacional.

Palabras clave: región; identidad; regionalización; Valle de Preševo; Serbia.

1 Department of Geography. University of Prishtina. Kosovo. arsim.ejupi@uni-pr.edu

2 Departamento de Geografía. Universidad Autónoma de Madrid, España. miguelb.bernabe@uam.es. * Corresponding author 


\section{Introduction}

\subsection{Preface}

The sense of belonging to a society within a region, formed when a significant part of inhabitants share symbols, values and aspirations creates regional identity and an own cultural system (Giménez, 2005). Unconsolidated borders, presence of frozen conflicts and gray zone tactics in Eastern and Southeastern Europe make this region of notable interest for the study of identity and their implications to geopolitics (Marcu, 2011; Bernabé-Crespo, 2020), where territorial exchange ideas derived by strong and differentiated identity -among others- may play a key role.

Located within Serbia, Preševo Valley lies just in the border with Kosovo and its major population is claimed to be Albanian. Between 1999-2001, the so-called Liberation Army of Preševo, Medveda and Bujanovac operated with the aim of breaking away from Yugoslavia and joining Kosovo. These ideas of border changes and exchanges of municipalities appear in order to create more ethnic homogeneous territories and stabilize the region politically, although risk of violence should also be contemplated and warned (Bernabé-Crespo, 2021). As Viales (2010) spots, national or bordering issues cannot be understood without transnational or global, also taking into account that the 'region' construct changes throughout time. The latter leads to reflect on how the influence of foreign actors may reshape the sense of regional identity. In the context of the Balkans, redrawing of borders is an issue commonly expressed by certain political thoughts, along with the external political interferences. When claiming a territory, historical rights are commonly appealed (Murphy, 1990), what shows the relevance of the study of the regionalization process. Acknowledging the recent history of this area in particular, the Balkans, and more specifically, Preševo Valley and the pursue of Albanian rights (Zejnullahi, 2015), it is of crucial importance to achieve a pacific coexistence by strengthening the process of State building which needs to respect ethnic minorities, and thus, different shapes of regional identities within a country (Horowitz, 1993; Finlay, 2011). This article first discusses the process of regionalization and its methodological principles, providing a theoretical basis for this study and analyzing the criteria used for categorization of the region as a unit of special importance within geographical research. Methodology is shown next, detailing the qualitative analyzes made through 328 interviews to the local population of Preševo Valley, as well as the description of the area of study, including an overview of the different naming made by different ethnic groups and political views. After this, a demographic analysis is carried out regarding the evolution of population and ethnic groups which inhabit this area and the results of the survey about the elements that compose their regional identity. Lastly, these are discussed bearing in mind the current situation of Preševo Valley and conclusions are finally presented.

\subsection{Theoretical background}

Depending on the criteria used in the literature, there is a number of definitions of the region as category and regionalization as a process. According to Petrović (1957) the number of different concepts and the wide possibility of combining them during the designation of a geographical region is due to the fact that many authors tried to develop it without explaining the concept of the latter. This concept is based on the dialectical unity of nature and society, which results by the formation of certain spatial units that are distinguished by a harmonious arrangement of natural and social elements, but also the interaction between them. This fact shows the complexity of such definition and highlights the need for a multidimensional approach to the study of regions as a geographical phenomenon and regionalization as a complex process.

'Region' is defined as a cohesive area that is homogeneous in the selected criteria. Geographers have widely studied the process of regionalization (Nogué, 1989; Plaza, 2001; Viales, 2010), also reflecting about the impact of globalization (Nogué, 2007).

The geographical region is thus conceived as a concrete, tangible entity, a physical reality that exists as a reference framework for the population living there (Contel, 2015). In Geography and Demography there is a doctrine that explains the integration, differentiation and functional organization of space in the context of the development of demographic processes (Tošić, 2012). The main hypothesis of this doctrine is based on the axiom that population has a determinant role within the country and changes in regions and regional urban systems. Therefore, research on population as a decisive factor in the regional structure include the analysis of demographic development in quantitative terms (natural and spatial 
mobility of the population), qualitative (changes in biological, social and economic structures), political, social and economic processes (employment, political organization, migration, depopulation), etc.

The task of a geographer is to explore and discover the importance of regions in geographical research the combination of factors responsible for such 'regional configuration' (Vujadinović and Šabić, 2017). Thus, homogeneity is taken as one of the main criteria in the process of regionalization. As a result, 'homogeneous region' refers to a spatial unit consisting of several basic elements with the same qualitative characteristics on the basis of which it differs from other units (Pavlović \& Šabić, 2006). In all parts of the homogeneous region there is a unique set of the most important structural elements, but also the development and the same intensity of their concentration, for example tropical rain forests, Sahara Desert, Alps, etc.

Another important feature of the region is the consistency that comes from the combination of natural and social features. This harmonious combination allows the identification and separation of a region from neighboring regions. A region as a construct represents the end product of a research process. The search for formal/homogeneous ('natural' or 'geographical') regions was a standard practice in traditional regional geography. The regions constructed by scholars were represented as bounded, contiguous entities in divisions of larger units into regions. 'Perceptual regions' were another example. Both bear witness to a 'bordering' process carried out by the researcher (Paasi, 2010). The region is at the core of geographical research, especially socio-geographical, as well as the basic principle of territorial regulation. The pragmatism of the above approach lies in the fact that the region represents a model for achieving a set of goals in the research framework (Ejupi \& Ramadani, 2016).

Breaking apart a large area into smaller regions is something known as the regionalization process. This is how geographers identify the parameters of regions within a greater area of space. For it to be useful, regionalization must break areas into practical units. Therefore, the regionalization process is not about creating regions as much as it is about identifying regions that already exist. Regionalization is an approach that aims to identify and determine homogeneous spatial units according to certain criteria. Each regional approach is based on the hypothesis of the division of space into certain units according to the variability of the features of one or more phenomena (Fuerst-Bjeliš, 2007). It represents a set of applied scientific and practical methods used to identify different regional structures. From this it can be understood that regionalization, in fact, is an applied part of Regional Geography. Regionalization is the process of creating a system of regions within the state area that enables the profiling of the region according to the dominant characteristics. It also represents one of the main approaches and principles of scientific knowledge about spatial differentiation, development orientation, planning and regulation of geographical space (Vojković, 2003). Regionalization is also a very important process from a social, economic and political point of view. It helps to regulate the state through its organization in certain regional units, preserve and improve the socio-economic order of the country, alleviate political differences, social and economic inequalities between different regional units within the state, etc.

From the initial phase of development of Regional Geography as a scientific discipline until today, several ideas and definitions of the region as a separate geographical category have been developed, and the importance of the criteria has also changed. Initially, regions were usually determined taking into account the physical factors of the area, with an emphasis on certain natural-geographical factors of a particular territory. Later, in addition to the analysis of the internal structure of such individualized units, other characteristics such as demography (population), economy, etc. were taken into account. Rogić (1963) emphasizes the changing role and importance of physical-geographical and social economic factors in the definition of these regions, depending on the size of the space defined in the regional aspect. While in most cases larger regional units that belong to higher levels of the hierarchy are mainly defined by the main natural-geographical features, in small spatial units, socio-economic factors play also an important role. With the aim of primarily designating regions in accordance with the criteria established in the principle of dominant physiognomy, functionality and homogeneity, other methodological aspects have made progress over time (García, 2006; Paasi, Harrison \& Jones, 2018).

Physical-geographical regionalization takes as a starting point the assumption that elements, factors and physical-geographical processes play a decisive role in regional differentiation, integration or regional organization of the geographical space. Nir (1990) displays different approaches related to systems theories. According to this view, a natural region is a part of geospace, the uniqueness and homogeneity that arises from the interaction of elements and geographical factors. Therefore, geospace is divided into 
large or small natural units that have similar characteristics as relief, climate, hydrology, biogeography and pedology.

The second approach of physical-geographic regionalization focuses in the differentiation of geographical space into more complex regional systems known as geocomplexes. Kulzcyk (2000) noted that geocomplexes as units having concretely defined boundaries remain one of the most often used reference areas in geographical research. They appear in two models: according to the first model, natural regions are the result of homogeneity, development of synergy and interactive relations of several processes, factors and elements. This form of regionalization makes it possible to distinguish complex regions. In the scientific literature these are known as 'geocomplexes' or 'natural landscapes'. According to the second model, which does not exclude the previous one, geocomplexes can be formed by merging and functional integration of several heterogeneous natural units formed in different ways and circumstances.

From this brief review of the definition of the region as a phenomenon and regionalization as an approach, it can be understood that there are different criteria for defining individual areas in regional frameworks, including the homogeneity of natural elements, social and economic factors, uniformity, perception and sense of regional affiliation, pragmatism, etc.

\section{Methodology}

\subsection{Area of study}

Located in the south of Serbia, Preševo Valley occupies a strategic position within the central part of the Balkan peninsula, between Morava valley in the north (where it naturally belongs to), and Vardar valley in the south (Figure 1), which rends this area of special strategic relevance in terms of connectivity and natural resources (Bernabé-Crespo and Peña-Ramos, 2019).

The use of the term 'valley' is even contested from a geomorphological term because the areas around Preševo are created by tectonic processes, there is no large water body. However, elements of the socioeconomic sphere such as the Albanian majority, demographic characteristics, backwardness in economic development, historical past and perception of the population of the same affiliation are those elements that give attributes of a separate geographical unit used in literature as Preševo Valley. It began to be used as a name during the war in Kosovo (1998) and the armed conflict in Preševo and Bujanovac, initially by American and European political and diplomatic circles and then Albanian ones. It should be pointed out that except this name there are also other names such as Kosova Lindore, (meaning 'Eastern Kosovo', which is sometimes used amongst Albanians) and Jug Centralne Srbije ('South of Central Serbia', which is used by Serbs) are inconvenient from scientific view and have political background. The notion 'Preševo Valley' has been contested by Serbian scientific community and is little mentioned. For example, Kostić (1969) mentioned the name 'Moravica Valley and the area of Bujanovac' and the area from Preševo watershed to Levosoje to be known as 'Moravica Valley'. According to this author, Moravica Valley is a separate entity, while Bujanovac area is integral part of the Vranje and Bujanovac valley. The same author mentioned the name 'Preševo Plain', (in Albanian: Fusha e Preshevës) in his paperwork in Vranjske Novine, Irić (2012) refers to an interview of well-known linguist M. Zlatanović who makes a clear distinction between the words 'valley' and 'plain', and builds on Trifunoski's ideas that the areas along the upper course of the river Tabanoci, Moravica and Preševo are an integral part of the so-called Valleys of Preševo and Kumanovo, as well as the low watershed between Morava and Vardar (Trifunoski, 1951). The common name for Preševo, Bujanovac and Medvedja remains in the function of a clearer articulation of the demands of the Albanian population for the realization of their civil and national rights.

According to regional and geographical studies, geographic space is not a chaotic mixture of components, elements and factors, but the above-mentioned units are grouped under certain laws, thus they built systems of different sizes where objects, processes and factors are harmonized inside a particular spatial unit. Because of this fact, it is necessary to make a regional differentiation of individual geographical areas.

This complexity requires application of theoretical methods and principles which make possible regionalization of a certain territory. The aim of this article is to characterize a singular region which entails great geopolitical importance, and appears to be threatened by ethnic confrontation. First, it is presented a theoretical background, followed by an overview about the geographical-regional differentiation. A deep analysis about Preševo Valley's identity is presented, which allows us to discuss about the use of the term regarding political spheres. 
Figure 1. Physical map of Preševo Valley

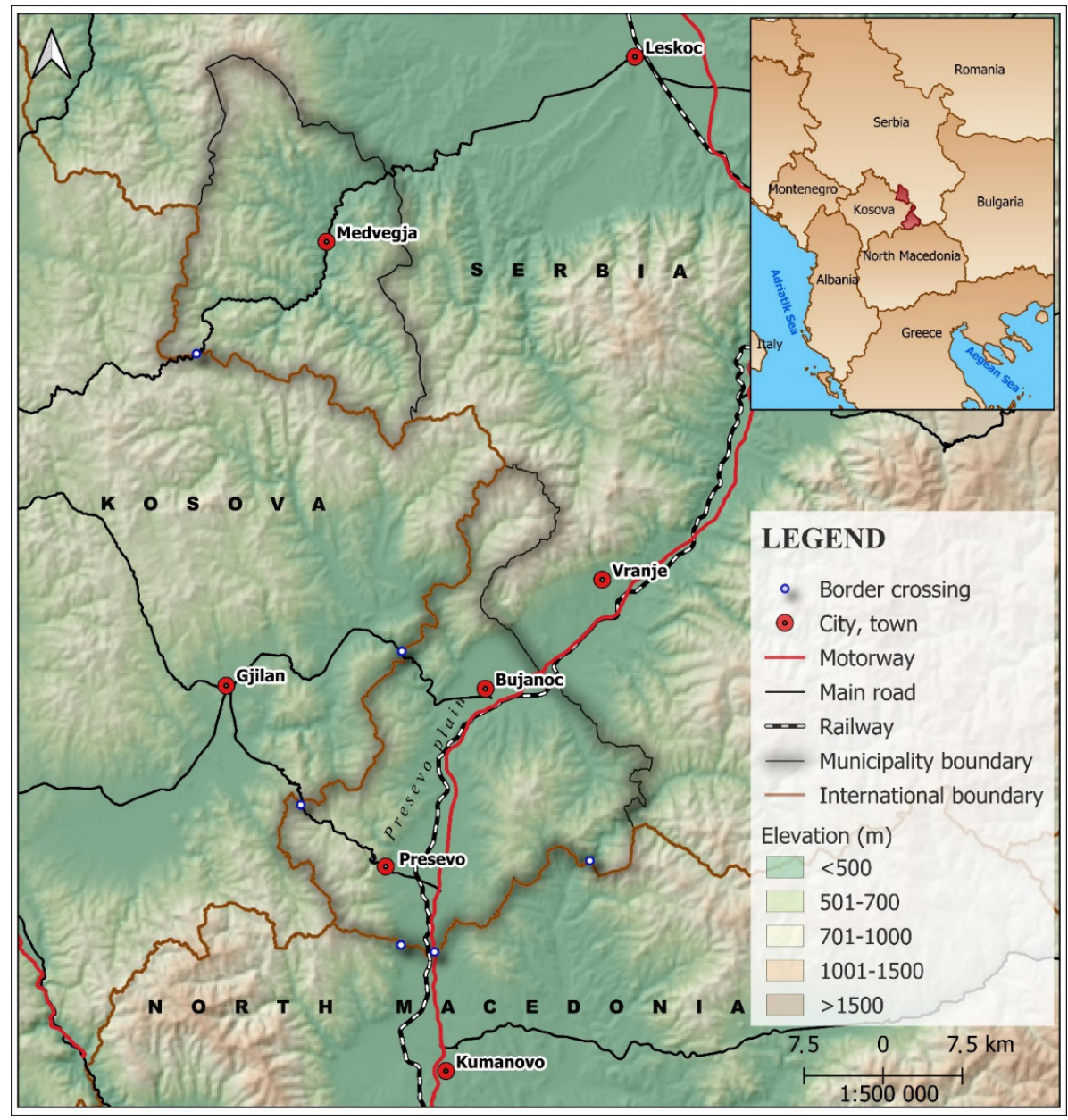

Own elaboration (by Kaltrina Misini)

\subsection{Method}

The large number and various aspects under which the regional-geographical differentiation of space is done, makes it clear that complex process of regionalization may take into account all the features that have spatial attributes. Thus, the method of regionalization itself was taken out of the framework of Geography as a classical science and acquired the character of a general method in all sciences that study spatial relations and phenomena from various aspects (Radovanović, 1994). For the purposes of our research object complex geographical analyzes and synthesis of basic natural, demographical and economic elements were used aiming to find common features that may give to the study area attributes of a unique region. Cartographic method was used to present main geographical units that point out physical and geographical heterogeneity on one hand, and territorial discontinuity between municipalities in Preševo Valley on the other hand, which itself represents the main obstacle during the process of regionalization.

In order to determine the regional identity of the population, a survey was conducted in June 2020 with 328 respondents (203 men and 125 women) in 62 settlements of the Preševo Valley, both in villages and in cities of the region. The questionnaire contained basic data on respondents while semi-closed questions dominated with the possibilities to give own answers which are different from those offered in the questionnaire. For the questions aiming to understand the degree of agreement or disagreement with the findings in the questionnaire, Likert Scale was used with five categories, ranging from 1 (strongly disagree) to 5 (strongly agree). Using this scale, we have tried to gather information about a topic by including a neutral answer option for respondents to select if they don't wish to answer from the extreme choices. During the analysis of the meaning and use of the name 'Preševo Valley' scientific works and cartographic sources on this area were used. Since the name 'Preševo Valley' is used by all residents, often 
without knowing its meaning, this research is intended to collect data on the contemporary perception of the name 'Preševo Valley'. Census data of different periods were also used to present ethnical composition of population and main economic characteristics.

\section{Results}

\subsection{Advantages and disadvantages of the process of regional-geographical differentiation of the Preševo Valley}

In the attempts to define the Preševo Valley in regional terms, certain difficulties are faced, which primarily derive from a certain degree of physical and geographical heterogeneity, especially geomorphological. The Preševo Plain is a unique morphological unit, while the area of Bujanovac is an integral part of the valleys of Vranje and Bujanovac; and Medvedja is separated and belongs to Jablanica watershed. All other natural-geographical elements, such as climate, water, soil, vegetation and landscape features have a high degree of homogeneity and uniformity (Marković, 1980).

Another obstacle that is obvious is the territorial discontinuity between Preševo and Bujanovac municipalities with Medvedja municipality. This fact highlights the political reasons of using the common name 'Preševo Valley', which will be discussed further in this paperwork.

Despite the low level of homogeneity of the physical-geographical components, Prěsevo Valley has demographic, social and economic homogeneity. One of the elements that has a high degree of homogeneity in the Preševo Valley is the population that fulfill the above criteria in all elements of the demographic regime with the same fertility and mortality rate, natural growth, with the same or similar intensity of development. Until now, all three municipalities had the highest birth and mortality rate in all Serbia, which results in a high natural growth.

Other structural features of the population of the Preševo Valley are also distinguished by a high degree of homogeneity, uniformity and consistency, where it should be mentioned the ethnic structure with dominance of the Albanians (Table 1). This important structural element is evident in Preševo and Bujanovac, while in Medvedja this intensity is disturbed due to a different ethnic structure of the population, where Albanians account a lower percentage of population than other ethnic groups.

Table 1. Ethnic structure of population in Preševo Valley for the period 1961-20023

\begin{tabular}{|l|r|r|r|r|r|r|}
\hline \multirow{2}{*}{ Ethnicity } & \multicolumn{2}{|c|}{2002} & \multicolumn{2}{c|}{1981} & \multicolumn{2}{c|}{1961} \\
\cline { 2 - 7 } & Number & \multicolumn{1}{c|}{$\%$} & Number & \multicolumn{1}{c|}{$\%$} & Number & \multicolumn{1}{c|}{$\%$} \\
\hline Albanians & 81,978 & 72.98 & 60,318 & 61.63 & 39,884 & 44.31 \\
\hline Serbs & 24,134 & 21.38 & 29,772 & 30.41 & 45,229 & 50.21 \\
\hline Roma & 4,306 & 3.91 & 4,646 & 4.74 & & - \\
\hline Others & 1,791 & 1.73 & 3,158 & 3.22 & 4,933 & 5.48 \\
\hline
\end{tabular}

Source: Census of population and households, year 2002, National or ethnic structure, Book I, results for settlements and municipalities. Own elaboration

According to the degree and type of homogeneity or heterogeneity, it is assumed that a compact ethnic composition consists of more than $90 \%$ of the total population of the same ethnic group. When they reach $80-89 \%$ of the total population, it is distinguished as 'significant ethnic homogeneity'; and between $70-79 \%$ as 'low homogeneity'. When these percentages account between $60-69 \%$ it is classified as 'high heterogeneity'; and between 50-59\% as 'significant ethnic heterogeneity'.

In addition to the percentage of the largest ethnic group, the coefficient of ethnic heterogeneity is used to determine the degree of homogeneity or heterogeneity of the population in a certain region (Table 2).

3 Censuses after 2002 are not considered valid for this area as they have been boycotted by the Albanian community, so this record is the latest official. 
This coefficient shows the number of members of all other ethnic groups together in 1000 members of the largest ethnic group.

Table 2. Percentage of biggest ethnic group and coefficient of ethnic heterogeneity

\begin{tabular}{|l|c|c|c|c|c|c|c|c|c|c|}
\hline & \multicolumn{4}{|c|}{ Percentage of biggest ethnic group } & \multicolumn{4}{c|}{ Coefficient of ethnic heterogeneity } \\
\cline { 2 - 15 } & $\mathbf{1 9 6 1}$ & $\mathbf{1 9 7 1}$ & $\mathbf{1 9 8 1}$ & $\mathbf{1 9 9 1}$ & $\mathbf{2 0 0 2}$ & $\mathbf{1 9 6 1}$ & $\mathbf{1 9 7 1}$ & $\mathbf{1 9 8 1}$ & $\mathbf{1 9 9 1}$ & $\mathbf{2 0 0 2}$ \\
\hline Preševo Valley & 50.2 & 53.3 & 74.7 & 85.1 & 73.1 & 990 & 440 & 350 & 266 & 368 \\
\hline Vojvodina & 54.9 & 55.8 & 54.4 & 56.8 & 65.1 & 822 & 793 & 817 & 762 & 537 \\
\hline Kosovo & 67.2 & 73.7 & 77.4 & 81.6 & - & 489 & 357 & 291 & 226 & - \\
\hline Serbia & 74.6 & 71.2 & 65.8 & 65.9 & 82.8 & 339 & 404 & 449 & 517 & 206 \\
\hline
\end{tabular}

Source: Population census, year 1961: Vital, ethnic and migration features, Book VI, Belgrade, 1967; Population census year 1971, Ethnic features of population, municipality results, Belgrade 1974; Population and households census, year 2002, National or ethic structure, Book I, Belgrade, 2003. Own elaboration

From the above data it is deduced that in the Preševo Valley, during the period 1961-1991 there has been a positive trend in percentage of the largest ethnic group, the Albanian. While in 1961 in the Preševo Valley Albanians consisted 44.3\% of the population, in 1991 this number was doubled and reached $85.1 \%$. These ethno-demographic processes were similar to those in Kosovo, where during the analyzed periods there is an evident continuous increase in the percentage of the largest ethnic group (Albanians), from $67.2 \%$ in 1961 to $81.6 \%$ in 1991.

Unlike the Preševo Valley and Kosovo, the ethno-demographic situation in Vojvodina and Serbia is completely different, with very small differences in the percentage of the largest ethnic group (Serbs). Thus, in Vojvodina this percentage changes in a positive direction from $54.9 \%$ in 1961, the participation increases to $65.1 \%$ in 2002, while Serbia's level shows a negative trend: it decreases from $74.6 \%$ in 1961 , to $65,9 \%$ in 1991 , followed by an increase to $82.8 \%$ in 2002 .

The coefficient of ethnic heterogeneity in the Preševo Valley marks a negative trend from 990 as it was in 1961, to 266 in 1991. In 2002 there is an increase of this coefficient to 368. Also, in Kosovo in the analyzed periods there is a decrease of this coefficient from 489 as it was in 1961, to 226 in 1991. The negative trend of the coefficient of ethnic heterogeneity in the Preševo Valley shows that in the analyzed periods there is a constant increase in the degree of ethnic homogeneity dominated by Albanians.

When it comes to the ethnic structure of a region it is important to know about the territorial extent of ethnic groups within the region. The Albanian population has an absolute dominance in the hillymountainous part of Karadak in the west, with a homogenous ethnic composition, as well as in the plain part of the region. The slopes of Rujan and the eastern part of the region is distinguished by a more significant ethnic heterogeneity. The territorial extension of the Albanians shows that their ethnic area is functionally and naturally linked with Kosovo and Kumanovo-Skopje area, mostly inhabited by Albanians.

In addition, biological, educational, linguistic, religious, social and economic structures show a high degree of homogeneity and uniformity through the whole area, dominated by young people, the majority of people belong to the Islamic religion. It has high but declining levels of illiteracy among the population, especially among women, with dominance of the rural population. There is a high participation of the agricultural population in the total population, extremely unfavorable ratio of the active population, unfavorable structure of the active population by economic activity, etc.

According to the basic indicators of economic development (income, gross national product per capita, unemployment rate, etc.), Preševo Valley and the Albanian population are characterized by a significant backwardness, both in absolute and relative terms. According to the Strategy for Regional Development of Serbia 2007-2012 the municipalities of Preševo, Bujanovac and Medvedja are the most underdeveloped in entire Serbia. In the municipality of Preševo, with Albanian majority, national incomes that are only $14.1 \%$ of the Serbian average. In 2002 these municipalities with just 154.4 US dollars, had only $16.2 \%$ of national income compared to the Serbian average. Therefore, the economic structure of the population is extremely unfavorable. Due to the lack of investment for the development of industrial capacities and other sectors of economy, the Valley remains an undeveloped region, with a very unfavorable economic structure. Meanwhile, according to the Spatial Development Strategy of the Republic of Serbia, 
the municipality of Medvedja belongs to the category of the most devastated as well as most depopulated municipalities in Serbia (Official Gazzete, 2004).

Preševo Valley, with a very low rate of socio-economic development and lack of investment in the secondary sector, has an unfavorable economic structure, with the dominance of the agricultural population, as well as the unfavorable ratio between active population and population without income, small number of population with income, dominance of the primary sector as well as extremely low participation of other sectors.

The valley is characterized not only by a low rate of economic activity of the population, but also by slow changes: from $39.1 \%$ in 1961 to $36.6 \%$ in 2002 (Table 3). This percentage is lower than Serbia's average of $49.3 \%$ as it was in 1991 . The population without incomes, although having a downward trend in percentage, still shows very high values, above the Serbian average. The population without incomes in 2002 had a percentage of $53.7 \%$, while in Serbia to this category belonged only $38.1 \%$ of the population. Such level and unfavorable tendency, especially when the volume of the general population increases, are the result of a number of factors and above all the economic underdevelopment and the unfavorable structure of the economy for a long time: the high percentage of the population cohort 0-14 years, as a result of the high rates of natural increase; low involvement of women in production and social activities; derived from these, the exponential increase of pupils and students, the influence of other social factors (traditions, norms) related to the engagement of women in economic and social life, shortcomings during registration of the active population, etc. (Islami, 1981, Sentić, Rančić, \& Đošić, 1971; Rašević, Mulina \& Macura, 1976).

Table 3. Population of Preševo Valley according to activity for the period 1961-2002

\begin{tabular}{|c|c|c|c|c|c|c|c|}
\hline \multirow{2}{*}{ Years } & \multirow{2}{*}{$\begin{array}{c}\text { Population } \\
\text { number }\end{array}$} & \multicolumn{2}{|c|}{ Active population } & \multirow{2}{*}{$\begin{array}{c}\text { With } \\
\text { incomes }\end{array}$} & \% & \multirow{2}{*}{$\begin{array}{c}\text { Without } \\
\text { incomes }\end{array}$} & \% \\
\cline { 3 - 4 } & & Number & $\%$ & & & & \\
\hline $\mathbf{1 9 6 1}$ & 90,046 & 36,242 & 39.1 & 1,234 & 3.1 & 52,876 & 57.7 \\
\hline $\mathbf{1 9 7 1}$ & 94,371 & 35,316 & 38.7 & 1,567 & 4.4 & 53,731 & 56.9 \\
\hline $\mathbf{1 9 8 1}$ & 93,458 & 35,369 & 37.8 & 2,603 & 2.8 & 55,487 & 59.4 \\
\hline $\mathbf{1 9 9 1}$ & 101,549 & 34,302 & 37.8 & 4,543 & 5.7 & 57,324 & 56.5 \\
\hline $\mathbf{2 0 0 2}$ & 88,996 & 32,540 & 36.6 & 8,176 & 9.7 & 47,785 & 53.7 \\
\hline
\end{tabular}

Source: Population census in Serbia: 1961, 1971, 1981, 1991 and 2002. Own elaboration

\subsection{Regional identity of Preševo Valley}

The diversity of geographical contents in the physical-geographical part is not the only criterion in the complex process of regional differentiation and regionalization. The individuality of each region, except natural, social and economic factors, is influenced by the behavior and attitude of each individual towards the region, or recognition of the environment as their own (local environment), the role and position of the individual in society, etc. This is studied as the affiliation (individual perception of geographical space) that any individual or even wider social groups (collective consciousness of regional affiliation) can have (Šabić \& Pavlović, 2007). In this way, by adding socio psychological attitudes of the population towards regional identity to the geographical criteria, the individuality of the geographical region is pointed out even more. The term 'regional identity' is often used in both cultural and sociological literature. The content is related to certain systems of socio-cultural values. In this way, regional identity is very close to the categories of cultural and national identity. Cultural identity is known to be an integral part of the whole set, such as race, territory, language, tradition, customs, religion, etc. On the other hand, national identity contains certain characteristics of cultural identity, but it has more to do with a sense of belonging and solidarity within certain ethnic groups. Regional identity refers either to the supposed distinctive natural and cultural qualities of a region, the identification of people with such a region or both aspects at the same time (Paasi, 2012).

It is consciousness and regional identity that make up the region as a mental construction. This mental construction arises from the spatial perception of the population about uniformity or diversity. The population of the Preševo Valley perceives the region as an area of the same tradition, history, culture and 
identity. Moreover, Preševo Valley is an entity that exists in the collective consciousness of the population, because there is a sense of connection and belonging that derives from a common origin, culture and history. The above-mentioned hypothesis is confirmed by field survey. A determining the permanent settlement (since birth) of an individual, the results show that the majority of respondents, (61.9\%) live permanently in the settlement from their birth, whereas $22.8 \%$ have migrated from other settlements of the Valley (Figure 2). In this category are included individuals and families who moved from the settlements of hilly-mountainous area, mainly in the plain area as well as from villages to the cities. Meanwhile, only $15.3 \%$ moved to Preševo Valley from other regions. Out of $70 \%$ of respondents answered that they never lived outside Preševo Valley, which is an indicator of the reduced spatial mobility of the population and also relates the strong linkages and identification between birthplace and the region to which they belong.

Figure 2. Linkages of residents with birthplace and region

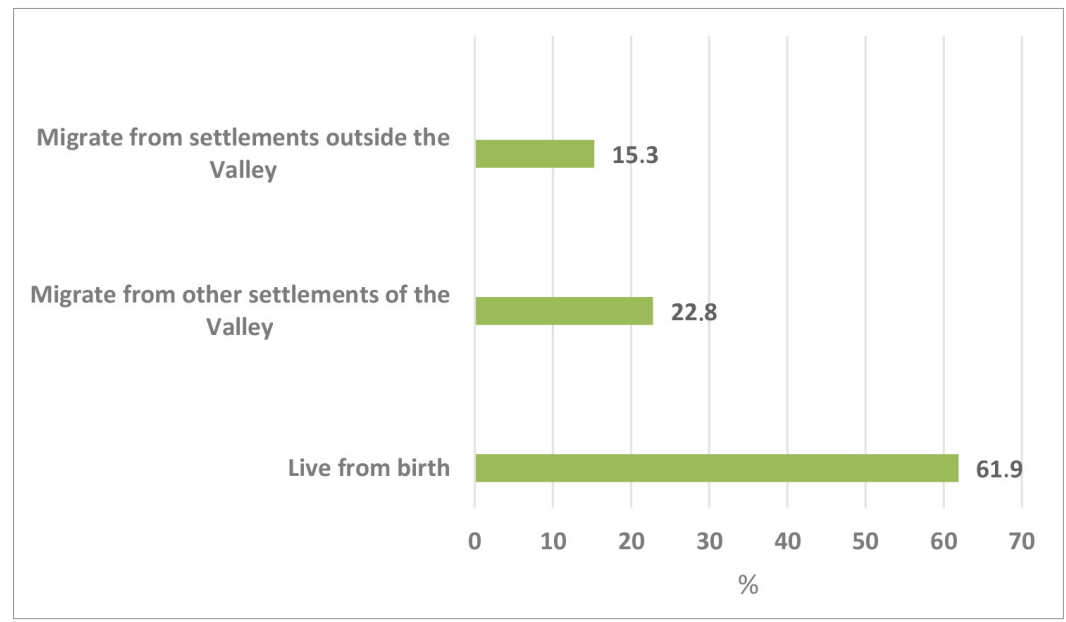

Own elaboration

When asked about their future, $77 \%$ of respondents stated that they had plans to live outside the Preševo Valley in the future, while only 23\% planned to stay in the region (Figure 3 ). This high percentage is caused by the very unfavorable economic, political and security circumstances that have for a long time dominated in the region. More than $49 \%$ of respondents said that the reasons of migration are lack of jobs. This is the way how especially young people think, because after they graduate, they have small choices to find a job. In this sense, $38.7 \%$ of them think that it is due to unstable political situation. Out of $34 \%$ will move due to better living conditions, while only $8 \%$ because of education.

Figure 3. Reasons of migrations within Preševo Valley's population

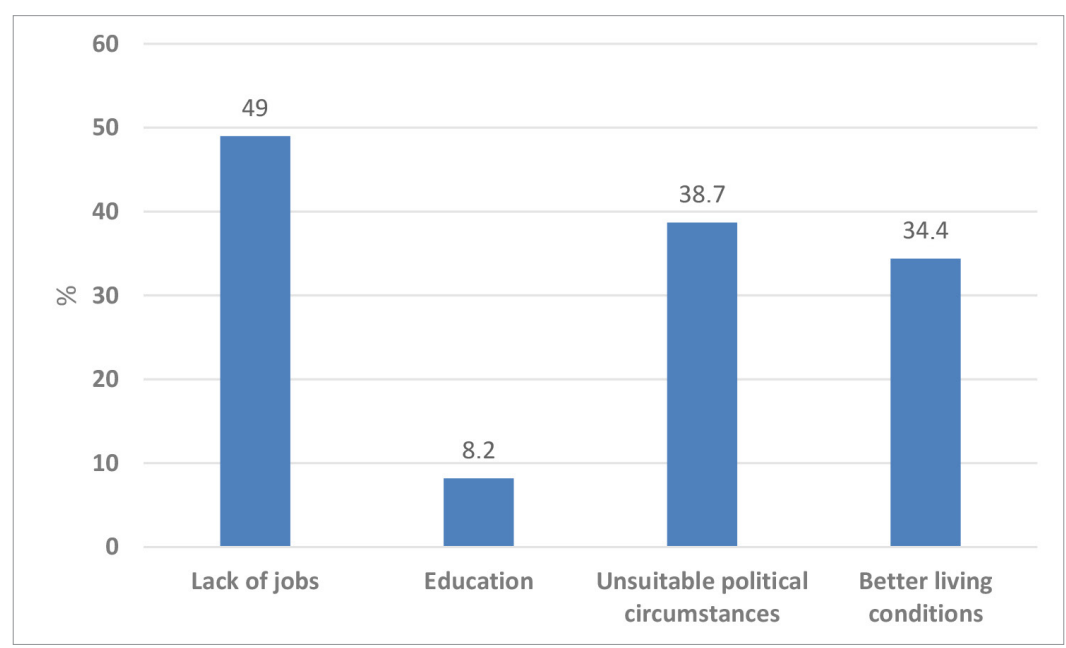

Own elaboration 
The purpose of the next question was to find some regional features that help to create a regional identity (Figure 4). Measured with the Likert Scale respondents rated the importance of language, cultural-historical heritage, trade, diaspora, food, and economic backwardness in the process of creation of regional identity. Out of $62 \%$ of respondents think that the diaspora is the most important element of regional identity. According to municipal authorities, about 30\% of the Valley's population lives abroad, which has an impact not just in the population number of the Valley but also in the economy of the region. Another identifying element is the language, which is the most important element for $51.5 \%$ of the respondents, while trade as the most important element of regional identity has pointed $43.3 \%$ of the respondents.

Figure 4. Main elements of regional identity

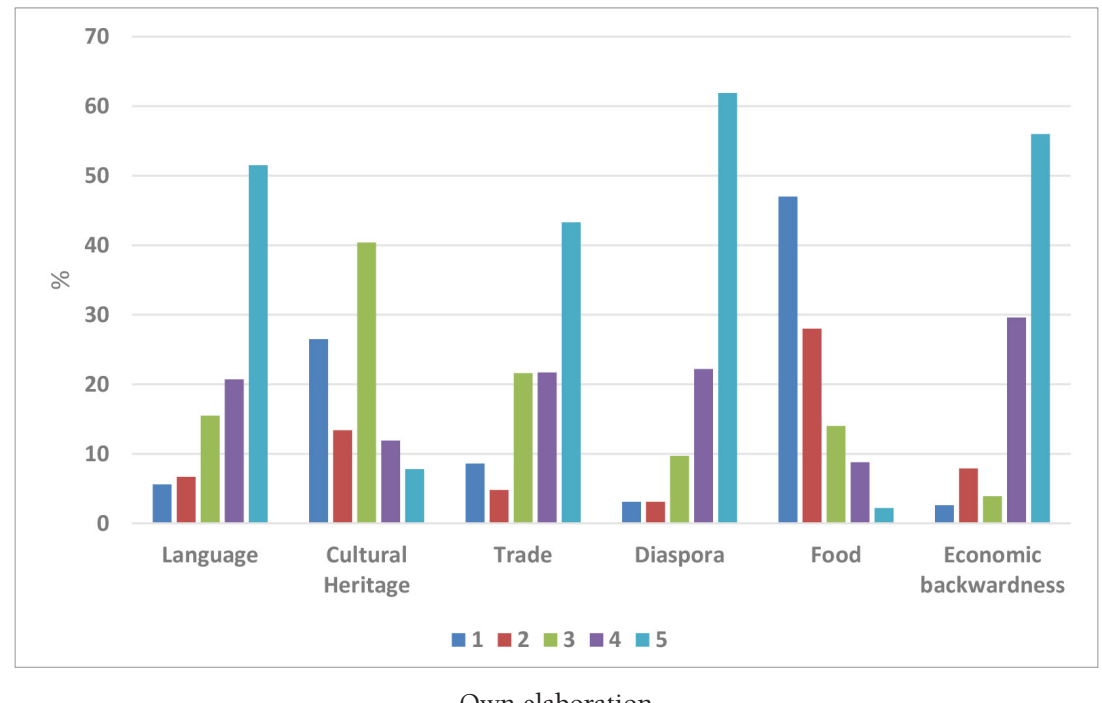

Own elaboration

Since Preševo Valley is located in Serbia, but has a cross-border position, the question about the cooperation that the Valley should have with certain regions and cities in vicinity, highlights the attitudes of the population for cooperation with Kosovo (Figure 5). Out of $90 \%$ of the respondents think that cooperation with Kosovo is the most important for Preševo Valley. Cooperation with Gjilan, which is a city located in the east of Kosovo, close to Preševo Valley is the most important for $55.8 \%$ of respondents; cooperation with Kumanovo, a city in North Macedonia, is the most important for $16.5 \%$ of respondents, while that Preševo Valley should have strong ties of cooperation with Vranje, which is the main administrative center of Pčinja district (Serbia) think only $0.4 \%$ of respondents.

Figure 5. Cooperation of Preševo Valley with neighboring regions and cities

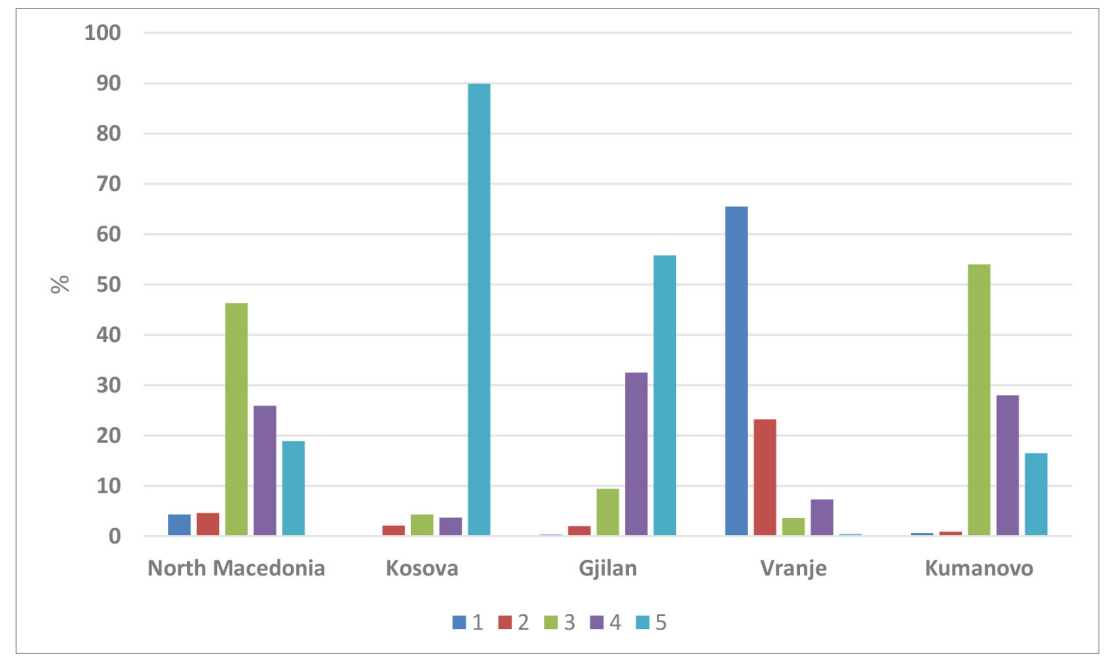

Own elaboration 
Local think that other 'outsiders' rather identify Preševo Valley as a border region, more precisely out of $68.9 \%$ of the respondents consider it as the most important element of identification (Figure 6). More than $56 \%$ of the respondents think that others know the Valley as a region located in Corridor $\mathrm{X}^{4}$. Out of $37 \%$ of the respondents say that foreigners know the Valley as a backward agricultural region, while the same percentage thinks that diaspora is the most important identifying element of others for the Valley.

Figure 6. How others identify Preševo Valley, according to locals

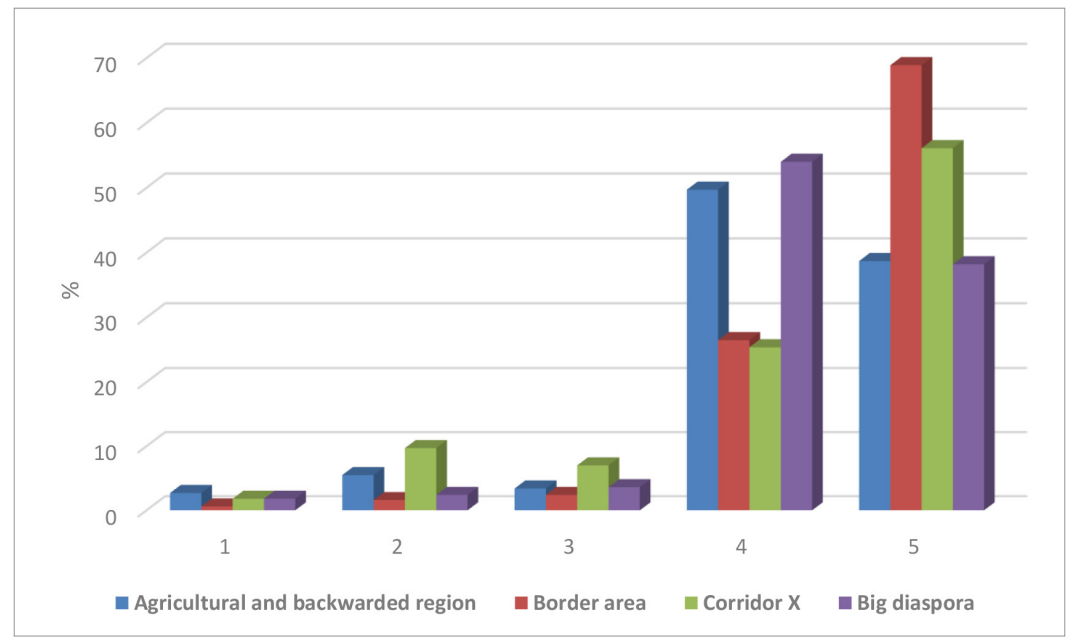

Own elaboration

Lastly, when asked what distinguishes Preševo Valley-Albanians from other Albanians in the former Yugoslavia, over 49\% of respondents consider national consciousness as the most important, 19.2\% language, and 10.2\% working attitudes (Figure 7 ).

Figure 7. What distinguishes Preševo Valley-Albanians from other Albanians

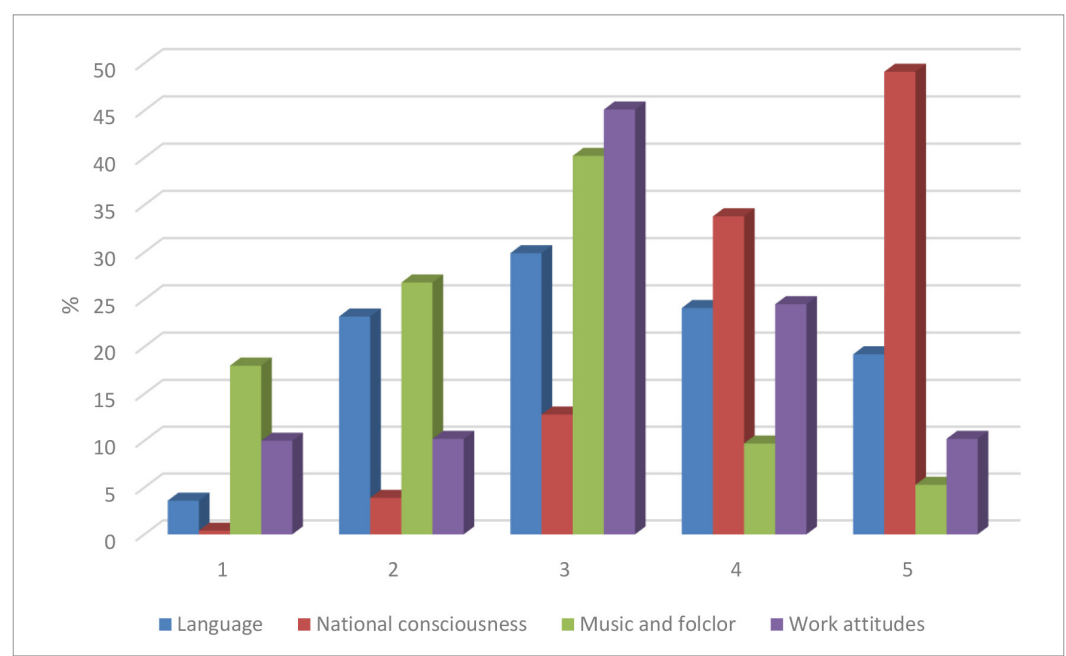

Own elaboration

\section{Discussion}

As previously shown, considering exclusively natural attributes does not allow the identification of an individualized region in Preševo Valley's area. Although the main territory of the municipalities

\footnotetext{
4 Pan-European transport corridor that passes through Preševo Valley (road and railway), connecting Belgrade (Serbia) with Skopje (North Macedonia) and Thessaloniki (Greece). This corridor represents an important link between central Europe and the eastern Mediterranean region (Islami and Ejupi, 2015).
} 
of Preševo and Bujanovac lies in the valley drained by the Morava River, Medvedjas municipality does not have connection with the rest of the natural unit. In this sense, naming 'Preševo Valley' to a region composed by these three municipalities does not correspond to natural attributes, in spite of occupying a major portion of this natural area. However, in the regionalization process, social elements must also be contemplated - the main hypothesis of the doctrine is that population plays a determinant role. Building on the concept on 'geocomplexes', Preševo Valley can be identified as one geocomplex, as it consists of different natural units (Preševo plain where Preševo and Bujanovac towns are located; and Medvedja hilly area) that due to similarities (social, economic, perception factors in addition to the proximity), share integrated functions derived from regional sense of belonging.

As for that, demographic analysis showed that Albanians represent more than $70 \%$ of population in Preševo Valley, which can be labelled as a society of a considerable homogeneity. It is interesting though to highlight the growing trend of the percentage (almost double 1961 figures, with an increase of $+28.67 \%$ ). If this trend continues, ethnic homogeneity will escalate. Moreover, more than $50 \%$ of the population do not count on any income, which rends this region with a high degree of poverty. When asking the survey respondents, one of the main reasons to migrate was the lack of jobs, and this migration process has affected the active population, which in 1961 represented $39.1 \%$ of the total population but in 2002 was of $36.6 \%$, as young and adults are more likely to flee this poor situation. This is why, among the respondents, $77 \%$ do not expect to stay in Preševo. These facts enhance the assumption that Preševo Valley is a region of emigration, where due to the economic circumstances, does not attract foreign population, nor even succeeds in retaining local people. If this hypothesis is correct, no new arrivals from other ethnic groups are expected to come, as this area would be known for its dominant Albanian population, lack of opportunities and high rates of emigration. It is necessary to reflect on how to amend this situation and which factors contributed to the backwardness. In this sense, government needs to carry out a comprehensive investment in the region in order not to create a sense of abandonment which tense relations between Albanian and Serbs. This means to equalize investment and equipment to all regions, especially in Preševo Valley, which seems to be left behind. It must be pointed out the strategic location of the Valley, the only natural corridor between Serbia and Greece -close allies-, which also connects Central Europe to the Aegean Sea. The main highway (A1) from Belgrade to Skopje, North Macedonia, passes through Preševo, the same as the main railway, where old factories can nearby be seen (Figure 8). This is of a special importance, as in a context of geopolitical tensions, strategic sites are disputed and often constitute spots where civil unrest is fomented - succeeding in mobilizing civil society suffering from high inequalities.

Figure 8. Budućnost factory of construction materials, near railway line in Preševo

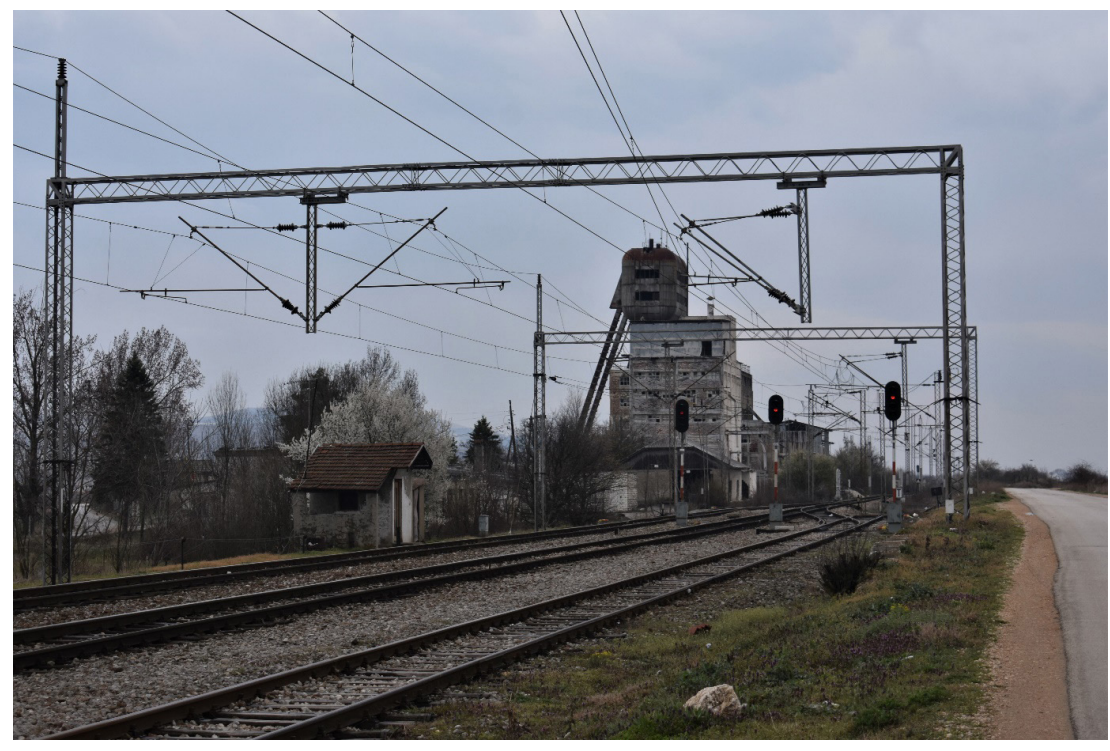

Photograph by M. B. Bernabé-Crespo

Collective consciousness of local population regarding identity is one of the main factor addressing demands for more civil rights and economic investments. In the survey, it was found out that Preševo 
Valley does gather elements of strong regional identity, driven by an increasing ethnic Albanian population which shares a sense of inequality towards investment and equipment. In addition, diaspora (62\%) was identified as the most important element of identity, followed by language (51.5\%) supporting the idea that identity is strongly driven by ethnic affiliation. Furthermore, the preferred ties of cooperation were associated to Kosovo, what represents a strong connection between Albanian people and the newly proclaimed state (Figure 9). This is of a special concern, taking into account the recent historical events that took place in 2001, where Preševo Valley's guerilla armed units fight in order to make this region join Kosovo; and more recently, the reiterate documents about the exchange of municipalities between states and border changes in the Balkans, known as 'non-papers'. Not in vain, local population of Preševo Valley think that their region is regarded by foreigners as a 'border region', what put them in the constant focus of different redrawing of boundaries and the creation of 'greater' motherlands. The last question of the survey stresses out that Albanians in Preševo Valley are distinguished by their national consciousness, meaning the close connection between them and Kosovo. This is another example of how regional identity is shaped within a singular region, that claims an equal treatment regarding development and stability.

Figure 9. Albanian flags in fighter's tombs and paintings supporting Kosovo in the town of Preševo

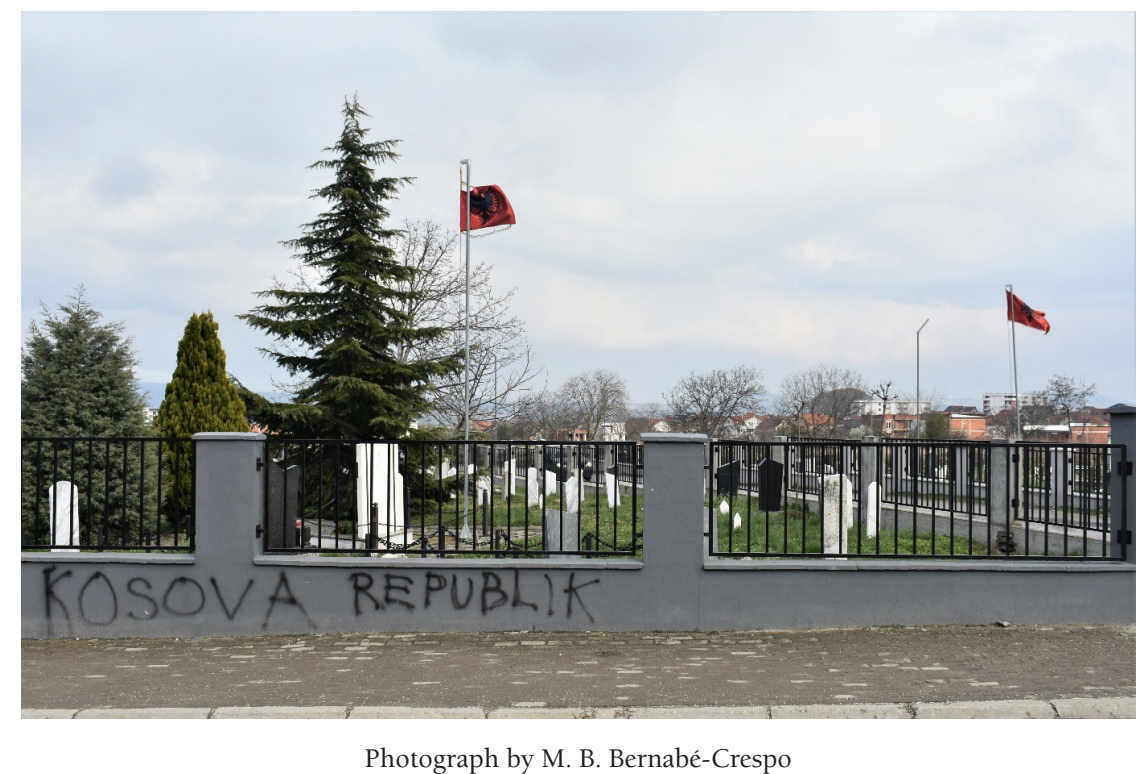

These considerations about regional identity within a contested area may play a key role in spaces where de-stabilization tactics are applied. Recently, in 2014 Donbass region in Ukraine was the scenario of a newly proclaimed units known as Donetsk and Luhansk People's Republics (DPR and LPR, respectively), which showed that, although not constituting an administrative region it represented indeed a case where cultural consciousness used a region as a scale - Donbass, characterized as a Russophile and industrial region with closer ties to Russia. Other example might be the recent tensions in Montenegro, where large demonstrations were held during the summer of 2021, showing confrontation between Serbian and Montenegrin nationalists, over the enthronement of the Serbian Orthodox Church patriarch in Cetinje, considered to be the royal capital of Montenegro. This last case shows a deep local identity that in a scenario of political interference can lead to civil unrest. Given this circumstances, studies over regional identity and regionalization may help addressing issues of improving cohesion and improving the process of State building, by respecting rights and alleviating and reducing conflicts that may appear in a context of external inferences.

\section{Conclusions}

The study of regional identity is a central issue amidst geopolitical contested areas and, in particular, when redrawing of borders is being promoted by some sector of the society. Through this analysis, a better understanding of cultural consciousness can be reached and, as a consequence, pacific coexistence 
in a State with different identities can be strengthened. In this article, the case of Preševo Valley was studied, although its procedures may be applied to other areas sharing similar features.

Morphological diversity, lack of natural cohesion and territorial-administrative discontinuity of the Preševo Valley are some of the shortcomings in the process of regional-geographical differentiation of the territory. However, history and geopolitics a high degree of homogeneity in the ethnic structure, with the dominance of Albanians, but also more elements of the demographic regime, severe economic backwardness and the collective perception of the Albanian population about regional identity seem to be the main factors that provide this area the attributes of a special region.

Albanians are the largest group in Preševo Valley, almost $73 \%$ of the total population in 2002. Active population is declining and the more than $50 \%$ do not have incomes, surpassing by a large extent Serbia's figures, which is a sign of the poorness of the region and derived from little investment. In the survey carried out in this study, it was found that almost $85 \%$ of the population was born in the Valley. Only $23 \%$ of them planned to stay in the region, and $49 \%$ of them planned to migrate because of the lack of jobs. When asked about the main elements that characterized Preševo Valley, diaspora, economic backwardness and language were the main features of identity. Being a strategic and cross-border region, respondents sued more cooperation with Kosovo, especially the city of Gjilan/Gnjilane; and thought it was not necessary to tighten relations to Vranje, Serbia. Regarding how others identify Preševo Valley, the nature of a border region seemed to be the main attribute, but also its position in the Corridor X, diaspora and agricultural and back warded region. Finally, according to the respondents, what distinguishes this local population from the rest of Albanians is their national consciousness the most.

Territorial discontinuity between the municipalities of Preševo and Bujanovac with Medvedja, but also the morphological diversity reduces the scientific justification for the use of the name 'Preševo Valley'. The use of this name by political and diplomatic circles, first American, then European and Albanian, was a necessity and a need to identify the population within a certain territory, with the purpose of a better articulation of their requests for individual and collective rights of Albanians in the Preševo Valley.

\section{References}

Bernabé-Crespo, M. B. (2020). Fronteras ocultas en la zona gris europea. Geopolitica(s), Revista de Estudios sobre Espacio y Poder, 11(2), 259-285. https://doi.org/10.5209/geop.64580

Bernabé-Crespo, M. B. (2021). La partición de Kosovo: ¿redibujar fronteras para conseguir la paz? Documents d'Anàlisi Geogrăfica, 67 (2). https://doi.org/10.5565/rev/dag.668

Bernabé-Crespo, M. B., \& Peña-Ramos, J. A. (2019). The management of water resources in a disputed border. The case of Gazivoda reservoir (Kosovo). Fronteiras: Journal of Social, Technological and Environmental Science, 8(1), 319-340. https://doi.org/10.21664/2238-8869.2019v8i1.p319-340

Contel, F. B. (2015). Concepts of region and regionalization: Aspects of its evolution and possible uses to health regionalization. Sauce Soc., 24(2), 447-459. https://doi.org/10.1590/S0104-12902015000200005

Ejupi, A., \& Ramadani, I. (2016). Regional differentiation and the geopolitical and transboundary position of the Presheva Valley. Miscellanea Geographica - Regional Studies on Development, 20(4), 22-28. https://doi.org/10.1515/mgrsd-2016-0024

Finlay, A. (2011). Governing ethnic conflict. Consociation, identity and the price of peace. Londres: Routledge. https://doi.org/10.4324/9780203847312

Fuerst-Bjeliš, B. (2007). Principles and methods of geographical regionalization. Zagreb.

García, J. (2006). Geografía regional. En D. Hiernaux-Nicolas y A. Lindón (Coords.), Tratado de geografía humana (pp. 25-70). Anthropos.

Giménez, G. (2005). Territorio e identidad. Breve introducción a la geografía cultural. Trayectorias, 7(17), 8-24. Retrieved from https://www.redalyc.org/pdf/607/60722197004.pdf

Horowitz, D. L. (1993). The Challenge of Ethnic Conflict: Democracy in divided societies. Journal of Democracy, 4(4), 18-38. https://doi.org/10.1353/jod.1993.0054

Irić, R. (2012). Geografija u političkom kazanu. Vranjske Novine.

Islami., H. (1981). Popullsia e Kosovës - studime demografik. Prishtina: ETMM te Kosoves.

Islami, H. \& Ejupi, A. (2015). Albanian population and settlements of Presheva Valley-present situation and trends. Prishtina: Kosovar Academy of Sciences and Arts. 
Kostić, M. (1969). Presevo Plain. Vranje Bulletin, 5, 144-147.

Kulczyk, S. (2000). The nature of boundaries of geocomplexes and the landscape types: the example of the surroundings of Pinczow in Southern Poland. Miscellanea Geographica, 9(1), 5-10. https://doi. org/10.2478/mgrsd-2000-090102

Marcu, S. (2011). Pax Russica: ambigüedad geopolítica de las tensiones y conflictos en el espacio de la antigua Unión Soviética. Investigaciones Geográficas, (55), 91-111. https://doi.org/10.14198/ INGEO2011.55.06

Marković, J. (1980). Regionalna geografija SFR Jugoslavije. Belgrade: Građevinska Knjiga.

Murphy, A. B. (1990). Historical justifications for territorial claims. Annals of the Association of American Geographers, 80(4), 531-548. https://doi.org/10.1111/j.1467-8306.1990.tb00316.x

Nir, D. (1990). Region as a Socio-environmental System. Dordrecht: Springer. https://doi.org/10.1007/97894-009-0483-5

Nogué, J. (1989). Espacio, lugar, región: hacia una nueva perspectiva geográfica regional. Boletín de la Asociación de Geógrafos Españoles, 9, 49-62. Retrieved from http://age.ieg.csic.es/hispengeo/ documentos/nogueespacio.pdf

Nogué, J. (2007). Paisaje, identidad y globalización. Fabrikart: arte, tecnología, industria, sociedad, 7 , 136-145. Retrieved from https://ojs.ehu.eus/index.php/Fabrikart/article/view/2227/1843

Official Gazzete of the Republic of Serbia (Službeni list Republike Srbije) (2004). number 63/04. Belgrade.

Paasi, A. (2010). Regions are social constructs, but who or what 'constructs' them? Agency in question. Environment and Planning, 42, 2296-2301. https://doi.org/10.1068/a42232

Paasi, A. (2012). Regional identities. In M. Juergensmeyer \& H. Anheimer (Eds.), Encyclopedia of Global Studies (pp. 1-12). London: Sage.

Paasi, A., Harrison, J., \& Jones, M. (Eds.) (2018). Handbook on the Geographies of Regions and Territories. https://doi.org/10.4337/9781785365805

Pavlović, M., \& Šabić, D. (2006). Regionalni pristup i tipovi regionalne diferenciacije teritorije. Bulletin of papers (Geografski Institut "Jovan Cvijić", SANU), 54, 204-218.

Plaza, J. I. (2001). ¿Una nueva geografía regional de España?: Algunas propuestas para su estudio. Boletín de la Asociación de Geógrafos Españoles, 32, 73-93. Retrieved from https://bage.age-geografia.es/ojs/ index.php/bage/article/view/403

Petrović, R. (1957). O problemu geografske rajonizacije Jugoslavije. Sarajevo: Geografski pregled.

Radovanović, M. (1994). Regionalizam kao pristup i regionalizacija kao postupak u funkcionalnoj organizaciji prostora sa nekim aspektima primene na Republiku Srbiju. Zbornik radova, 44-45, GIJC, SANU, Beograd, p.74.

Rašević, M. Mulina, T, Macura, M. (1976). Determinante ekonomske aktivnosti stanovnistva Jugoslavije. Belgrade: Ekonomsko Institut.

Rogić, V. (1963). Geografski koncept regije. Hrvatski Geografski Glasnik, 25(1).

Šabić, D., \& Pavlović, M. (2007). Regionalna svest i regionalni identitet. Zbornik Radova, 55, 151-158.

Sentić, M., Rančić, M., \& Đošić, D. (1971). Ocena nekih definicija i klasifikacija u popisu stanoništva 1971. godine. Belgrade: CDI, IDN.

Tošić, D. (2012). Principi regionalizacije. Belgrade: Univerzitet u Beogradu, Geografski Fakultet.

Trifunoski, J. (1951). Kumanovsko-Preševska Crna Gora. Knjiga 33. Belgrade: SANU.

Viales, R. J. (2010). La región como construcción social, espacial, política, histórica y subjetiva. Hacia un modelo conceptual/relacional de historia regional en América Latina. Geopolítica(s) Revista de Estudios sobre Espacio y Poder, 1(1), 157-172. Retrieved from https://revistas.ucm.es/index.php/GEOP/ article/view/GEOP1010120157A

Vojković, G. (2003). Stanovništvo kao element regionalizacije Srbije. Stanovništvo, 1-4, 7-42

Vujadinović, S., \& Šabić, D. (2017). The importance of regions in geographical research. Collection of Papers, 65(1a), 195-208. https://doi.org/10.5937/zrgfub1765195V

Zejnullahi, V. (2015). Albanians in Presevo Valley and their national rights. European Journal of Language and Literature Studies, 2(1), 89-94. https://dx.doi.org/10.26417/ejls.v2il.p90-99 